make, e.g., rotating internships of interest to general practice. Why could previous house officers not come back from general practice as registrars for two weeks? Why should general practitioners not conduct rounds in hospitals at times? Would the Royal College of Physidians of Edinburgh allow General Practice to be taken as a specialty in their membership examination?

DR. HORDER asked whether the rotating house officer worked for several specialists simultaneously or consecurtively.

DR. Paton replied that several posts were held at the same time-but this was merely a geographical convenience.
DR. HORDER thought it an excellent idea that the practitioner should return as a registrar. When he conducted rounds, was it on his own cases, or on the consultant's?

Dr. Paton meant the practitioner should take the round, discussing the later domiciliary management of all the patients with the consultant present.

DR. HORDER thought this experiment would be well worth while, but it was not easy to do a round on another's cases. Perhaps a number of general practitioners should take part, each seeing their own patients.

\title{
CONTINUING EDUCATION
}

\author{
J. W. Paulley, M.D., F.R.C.P. \\ Consulting Physician, Ipswich Hospitals.
}

THERE may be little left to be said about Postgraduate or Continuing Medical Education, but there will always be room for opinion on emphasis. For example, when just now Professor Le Quesne suggested that the pregraduate period should be mainly academic and untrammelled by technique, while the preregistration period should be essentially practical without too many distracting seminars, this was rather too "either-or" for me. Although we both believe in a continuum, I see the need for the junior medical student to meet more, not less, patients, if he is not to lose enthusiasm, and the preregistrand to attend more not less, seminars and journal clubs, if continuing education is ever to have any meaning.

As I have spoken and written too much on this subject already (Paulley, 1963, 1965) I propose today to speak to it, rather than about it.

Firstly, there is the Medical Library. In some circles reading has become unfashionable. Tape-recordings? - Of course. Teaching Machines?-Mandatory. Postgraduate Courses? -Naturally, one is paid to be a captive audience. Television?-Could we say it is in vogue, even if like the Welfare State it flows over us in a treacly stream hardly leaving a memory? But when it comes to reading, apart from certain dubious accretions to the Medical Press the contemporary answer is unenthusiastically damning. Frankly, I believe this is nonsense, and until every doctor spends one hour, or better still, two half-hours a week in a medical library continuing education will continue to fail. Furthermore it should be a periodical library, and not one full of text-books most of which are out of date by the time they roll off the presses. To achieve this there has to be a convulsion in the medical schools and the minds of the examiners. The student must be taught to use libraries so that by the time he graduates the reading of periodicals will have become an ingrained habit, and it follows that every doctor in future must have a periodical library within reasonable access. Bars in the new postgraduate centres are all very well, but could it be that libraries are more important?

Even today in those last remaining bastions of reaction what happens to the student who quotes the "B.M.J." (let alone "The Lancet") to his chief or registrar? It is usually "Don't waste your time with that stuff, you won't need it in finals". What is so sad is the excellence of the advice.

It is said that libraries in postgraduate centres have trouble over losing books. One sympathises, but it really serves them right for not concentrating on periodicals! A bound volume of J.A.M.A. is no vade mecum, and the $\mathrm{New}$ England J. Med. is equally unattractive in bed. It is true that unbound periodicals have been known to reach odd places such as lavatories, but if the library stamp is lurid and prominent, and if the library is sufficiently prized by its users, as we have found in Ipswich, then public opinion discourages pilfering and losses are very small indeed. An efficient librarian is, of course, essential, and the library should be open at all times. As the story of the Ipswich Medical Library has been described elsewhere no more will be said about it now.

My second plea is directed against didactic 
teaching. Most regional consultants recognise their responsibility to teach but continue to fall down over technique. This is due to an inherent fault in our educational system (not only medical) which remains too didactic. We are all addicted to the disease of lecturing and the cult of infallibility, while the attainment of seniority finds us imprisoned by our experience and poorly equipped to encourage discussion and accept criticism. In this context I have described elsewhere (Paulley, 1963) the "Friday Club" and Journal Club in Ipswich which have met with some success; the aim has been to achieve that degree of active participation by all present so rarely possible in a formal lecture. Indeed, one wonders how much longer the medical schools can afford to continue to use the lecture as a staple form of teaching. Only last week I heard of a school having difficulty getting students to attend a certain course of lectures. Did the authorities ask why? Probably not, because their only response was to make signing-in compusory.

Another thing which gets in the way of continuing education is the present disastrous split in the profession. I believe this starts in the Medical Schools where the student too often hears unthinking denigration of general practice and general practitioners. This may sound harsh but we know it to be true. It is not hard to imagine the conscious or unconscious sense of failure, however unjustified, that many of these men and women must feel when they themselves enter general practice. Yet the obverse shows these self-same critics, all too ignorant of human problems and the most elementary psychodynamics, condemned to practice medicine with a life-long hemianopia of which they remain astonishingly oblivious.

It is clearly not enough for the medical schools to spawn doctors, if the confused and unhappy state of so many young graduates is to be a thing of the past, and be replaced by the attitude of the permanent student. Failure could mean the degeneration of the finest of Postgraduate Centres into drab "speakeasies" with a commensurate clientele.

Finally, we should beware of making postgraduate education a cult, or an excuse for verbose publication. Instead it should be a worthwhile way of life and we should be grateful to those who have made it possible; I am thinking especially of the Nuffield Provincial Hospitals Trust coupled with the names of Sir George Pickering and Dr. Ellis.

\section{REFERENCES}

Paulley, J. W. (1963): Continuing Eduoation in a Area Hospital, Postgrad. med. J., 39, 321.. (ె) Paulley, J. W. (1965): Postgraduate Medical Edu? cation in a Provincial Hospital, Postgrad. med. J., 41, 213.

\section{DISCUSSION}

DR. P. ForGacs (Woolwich) asked for further advice about the organisation of libraries. He pleaded for research facilities for regional hospitals, and even for general practitioners, for clinicians who have no access to laboratories. Regional hospitals were in a favourable position to co-ordinate group studies carried out by general practitioners.

DR. Paulley replied that there must be a well equipped area library of periodicals, taking 100 journals and a limited number of text books from a lending library. Every department should have its small library of working text books as essential equipment, perhaps costing $£ 10$ a year. He entirely agreed with the suggestion about research. At Ipswich they hoped to have two rooms set aside for anyone wanting to do this. There was a more ambitious plan for the new distriat hospital.

Prof. Le Quesne denied that he had advocated a complete distinction between pre-graduate and preregistration training: rather he had stressed that this was a continuous process, with a shift of emphasis. He recommended that Dr. Paulley should go back to a medical school, to see for himself that progress was being made in undergraduate training as in postgraduate
DR. PAulley was reassured to hear that Professor Le Quesne did not mean to pose the "either or" alternative, but he believed that too much formal lecturing still went on.

Prof. Hubble said that at Birmingham they thought that some subjects needed to be taught by lectures and that some people were good lecturers.

SIR GeORge PICKERING thought that Dr. Paulley was absolutely right. He used to serve on the Medical Committee of the University Grants Committee and visit medical schools-in only one in the country were students to be found reading journals.

Prof. Hubble said that a great deal of reading of current journals was going on.

Mr. P. S. Boulter (Guildford) said that many of $N$ the men working at medical centres were going to $\mathcal{O}$ have to pass higher examinations. What about the teaching of the basic sciences? Some sont of unified early structure for a collection of disciplines was desirable but examinations made this impossible. Is a common basic science syllabus possible, and can this be taught in peripheral centres?

DR. Paulley replied that at Cambridge Dr. Jolly, an Ipswich anaesthetist, had got great co-operation from the University: men could now go from all 
over East Anglia for one day regularly to learn the basic sciences. It was very difficult to do this in a small town without a university.

DR. RINSLER (St. Stephen's) said that these subjects could not be taught without practical instruction. Centralised agencies and adequate teaching-probably full-time-were necessary.

Prof. McGirr (Glasgow) asked what we were trying to teach, from the physician's point-of-view. Not academic physiology! They should be learning applied physiology from clinicians. He wondered if they needed to be too closely associated with a basic science department.

Dr. Paulley thought that the accent might be changed in the examinations.

MR. M. R. WILliamS (Canterbury) said that there were two essentials-the tutor must provide a series of 'fringe' lectures for all residents, while the Regional Board must pay for attendance at specialised courses for examinations.

DR. Paulley agreed, apant from the word 'lectures'. Mr. WiLliams answered that 'lecture' was a general term. No one talked for more than 30 minutes and a discussion followed.

Dr. Paulley said that lecturers needed education in handling a discussion, they too often 'killed' it.

DR. MAOKeITH said that training in the basic sciences need not include a whole-time period but it needed to be regular (e.g. one day a week) and systematized. Specially helpful is a combination of teachers-for instance, a university teacher of neuroanatomy, with a neuro-surgeon to supplement him on the clinical side. 